\title{
Nitrogen Fertilization of Grass Leys: Yield Production and Risk of Nitrogen Leaching
}

\author{
Elena Valkama ${ }^{1}$, \\ elena.valkama@luke.fi; \\ Katri Rankinen²; \\ Perttu Virkajärvi';
}

${ }^{1}$ Natural Resources Institute Finland (Luke), Finland;

${ }^{2}$ Finnish Environmental Institute, Finland

\author{
Tapio Salo ${ }^{1}$; \\ Petri Kapuinen'; \\ Eila Turtola ${ }^{1}$
}

\begin{abstract}
The soil surface balance of nitrogen $(\mathrm{N})$, calculated as the difference between $\mathrm{N}$ inputs and output, is a principal agri-environmental indicator that provides information on the potential loss of $\mathrm{N}$ to surface or groundwater. (Research purpose) Determination of relevant models of yield response to $\mathrm{N}$ fertilization could prove helpful in minimizing $\mathrm{N}$ balance and simultaneously maintaining high-yield production. (Materials and methods) The authors used meta-analysis to quantitatively summarize $40 \mathrm{~N}$ fertilization experiments on perennial grass leys in Finland and assessed the effect of inorganic $\mathrm{N}$ fertilization on grass yields and $\mathrm{N}$ balances, and further estimated potential to reduce $\mathrm{N}$ input and $\mathrm{N}$ balances. The relationship was estimated by using the COUP model (a coupled heat and mass transfer model for 'soilplant-atmosphere' systems) and by reviewing the 12 Nordic studies on $\mathrm{N}$ leaching experiments involving lysimeters and drained field plots. (Results and discussion) It was found that the optimal N content in mineral soils is 230 kilograms per hectare, in organic - 190. In the first case, the economic effect of nitrogen introduction is 206 euro per hectare, in the second one - 62. (Conclusions) The developed yield response models can serve to construct a dynamic tool for growers to adjust $\mathrm{N}$ applications for maximizing economic profitability. The authors proved that the values predicted by the COUP model for $\mathrm{N}$ leaching losses after the application of mineral $\mathrm{N}$ fertilizer to perennial grass leys were in accordance with the low values measured, which ranged from 1.2 to 10-15 kilograms per hectar a year in Finland and in the Nordic-Baltic countries. It was also revealed that a possible risk of $\mathrm{N}$ leaching losses when using only inorganic $\mathrm{N}$ fertilization seems less crucial due to its low level and weak association with $\mathrm{N}$ balances.
\end{abstract}

Keywords: yield; grass leys; nitrogen balance; nitrogen leaching; meta-analysis; coupled heat and mass transfer model.

I For citation: Valkama E., Rankinen K., Virkajärvi P., Salo T., Kapuinen P., Turtola E. Nitrogen fertilization of grass leys: yield production and risk of nitrogen leaching. Sel'skokhozyaystvennye mashiny i tekhnologii. 2019. Vol. 13. N2. 31-39. DOI 10.22314/2073-7599-2018-13-2-31-39 (In English).

\section{Внесение азотных удобрений на лугах и пастбищах: урожайность и риск азотного выщелачивания}

\author{
Елена Валкама', \\ elena.valkama@luke.fi; \\ Катри Ранкинен²; \\ Пертту Виркаярви;
}

\author{
Тапио Сало; \\ Петри Капуинен ${ }^{1}$; \\ Эйла Туртола ${ }^{1}$
}

${ }^{1}$ Институт природных ресурсов Финляндии (Луке), Финляндия
${ }^{2}$ Финский институт окружающей среды, Финляндия

Реферат. Баланс содержания азота в верхнем слое почвы, рассчитанный как разница между количеством внесенного и остаточного азота, считается основным агроэкологическим показателем, который предоставляет информацию о возможном выносе азота с поверхностными или грунтовыми водами. (Цель исследования) Определить модели зависимости урожайности зеленой массы от количества внесенного азотного удобрения, которые могут быть использованы для минимизации баланса азота и одновременного поддержания высокого урожая трав. (Mamepuальl u методы) На основе мета-анализа осуществили количественную оценку результатов 40 опытов по азотной подкормке многолетних травяных угодий в Финляндии. Изучили влияние неорганического азотного удобрения на 
урожай трав и баланс азота, а также перспективы снижения потребления азота и баланса азота. Для оценки использовали сопряженную модель тепломассопереноса для систем «почва - растение - атмосфера». Осуществили 12 экспериментов по выщелачиванию азота в северных широтах. Провели лизиметрические исследования. Изучили осушенные участки лугов и пастбищ. (Результаты и обсуждение) Установили, что оптимальное содержание азота в минеральных почвах составляет 230 килограммов на гектар, в органических - 190. В первом случае экономический эффект от внесения азота равен 206 евро на гектар, во втором - 62. (Bblводыl) Разработали модели влияния на урожайность трав, которые сельхозпроизводители могут использовать в качестве динамического инструмента для регулирования нормы внесения азота, чтобы получить максимальный экономический эффект. Показали, что значения, прогнозируемые с помощью сопряженной модели тепломассопереноса для оценки потерь азота вследствие выщелачивания после внесения минерального азотного удобрения на многолетние травяные угодья, соответствовали низким фактическим показателям, полученным в ходе исследования, которые варьировались от 1,2 до 10-15 килограммов на гектар в год в Финляндии и в северных балтийских странах. Выявили, что возможный риск потерь азота вследствие выщелачивания при использовании только неорганического удобрения представляется менее критичным из-за низкого уровня этого элемента и его слабой связи с балансом азота.

Ключевые слова: урожайность; травяные угодья; азотный баланс; выщелачивание азота; мета-анализ; сопряженная модель тепломассопереноса.

【 Для цитирования: Валкама Е., Ранкинен К., Виркаярви П., Сало Т., Капуинен П., Туртола Э. Внесение азотных удобрений на лугах и пастбищах: урожайность и риск азотного выщелачивания // Сельскохозяйственные машины и технологии. 2019. Т. 13. N2. C. 31-39 DOI 10.22314/2073-7599-2018-13-2-31-39.

I $\mathrm{n}$ the Nordic-Baltic countries, grass leys usually receive substantial amounts of $\mathrm{N}$ fertilizer, which may lead to high $\mathrm{N}$ balances of up to $130 \mathrm{~kg} \mathrm{ha}^{-1} \mathrm{yr}^{-1}$ [1]. Reducing $\mathrm{N}$ inputs should prove to be an effective environmental practice that directly affects soil $\mathrm{N}$ balances, as demonstrated for spring cereals [2]. Moreover, adjusting $\mathrm{N}$ input according to yield response models causes no economic loss.

Soil surface $\mathrm{N}$ balance is a principal agri-environmental indicator that provides information on the potential loss of $\mathrm{N}$ to surface or groundwater. However, the link between $\mathrm{N}$ balance and $\mathrm{N}$ leaching loss from grass leys as well as from cereals measured at field and catchment scales is often complex and may vary widely across different soils, crops, $N$ sources and managements $[1,3,4]$. For grasses, in only a few studies on sandy soils, did researchers calculate the regressions for ungrazed [5] and grazed [6] grassland fertilized with both inorganic $\mathrm{N}$ fertilizers and slurry. According to the regressions, for example, an average European N balance of $65 \mathrm{~kg} \mathrm{ha}^{-1} \mathrm{yr}^{-1}$ [7] would correspond to an $\mathrm{N}$ leaching loss of $18 \mathrm{~kg} \mathrm{ha}^{-1} \mathrm{yr}^{-1}$ [5] or $30 \mathrm{~kg} \mathrm{ha}^{-1} \mathrm{yr}^{-1}$ [6]. Although these losses seem adequate for slurry applications, they may represent overestimations when applying only inorganic fertilizer to ungrazed grassland.

THE RESEARCH PURPOSE is to explore the relationships between $\mathrm{N}$ rates and grass yield responses, $\mathrm{N}$ balances, and $\mathrm{N}$ leaching loss, after applying only inorganic $\mathrm{N}$ fertilizer to ungrazed perennial grass leys.

Materials and Methods. For this purpose, we summarized 40 relevant Finnish field experiments conducted on mineral and organic soils during the last five decades and estimated the potential to reduce $\mathrm{N}$ balances without sacrificing yield. We further estimated
$\mathrm{N}$ leaching losses from $\mathrm{N}$ balances by using the COUP model and by reviewing the 12 Nordic studies on $\mathrm{N}$ leaching experiments involving lysimeters and drained field plots.

The database of grass yield response to inorganic $\mathrm{N}$ fertilization consisted of published and unpublished reports of experiments conducted at MTT Agrifood Research Finland (Jokioinen, Finland) and other Research Stations. The main grass species were timothy (Phleum pratense L.), meadow fescue (Festuca pratensis L.), cocksfoot grasses (Dactylis glomerata), and a mixture of them. In addition, two studies included tall fescue (F.arundinacea) and bromegrass (Bromus inermis).

Altogether 40 experiments took place between 1957 and 2004 at 17 sites on clay - 11 studies, coarse-textured mineral soils -21 studies and organic soils -8 studies (Fig. 1). A total of 28 studies reported ranges of soil pH, determined in water suspension, from 4.7 to 7 , and of the precise soil organic matter (SOM) content in topsoil, from 2.5 to $45.7 \%$. Four studies reported SOM content as a class ("medium", 3-6\%, or "rich", 6-12\%), while the remaining eight studies failed to report it. Fertilizer $P$ (mean $40 \mathrm{~kg} \mathrm{ha}^{-1}$ ) and $\mathrm{K}$ (mean $100 \mathrm{~kg} \mathrm{ha}^{-1}$ ) were applied according to the existing recommendations in order to provide sufficient amounts for grass growth. The annual application of $\mathrm{N}$ ranged from 50 to $600 \mathrm{~kg} \mathrm{ha}^{-1}$.

Response and explanatory variables

As response variables, the database for the metaanalysis included the total DM of the grass leys $(\mathrm{kg}$ $\left.\mathrm{ha}^{-1}\right)$ and $\mathrm{N}$ balance $\left(\mathrm{kg} \mathrm{ha}^{-1} \mathrm{yr}^{-1}\right)$. We calculated the soil surface $\mathrm{N}$ balance as described in [8]:

$N$ balance $\left(\mathrm{kg} \mathrm{ha}^{-1} \mathrm{yr}^{-1}\right)=N$ input $\left(\mathrm{kg} \mathrm{ha}^{-1} \mathrm{yr}^{-1}\right)-$ $-N$ output $\left(\mathrm{kg} \mathrm{ha}^{-1} \mathrm{yr}^{-1}\right)$, 


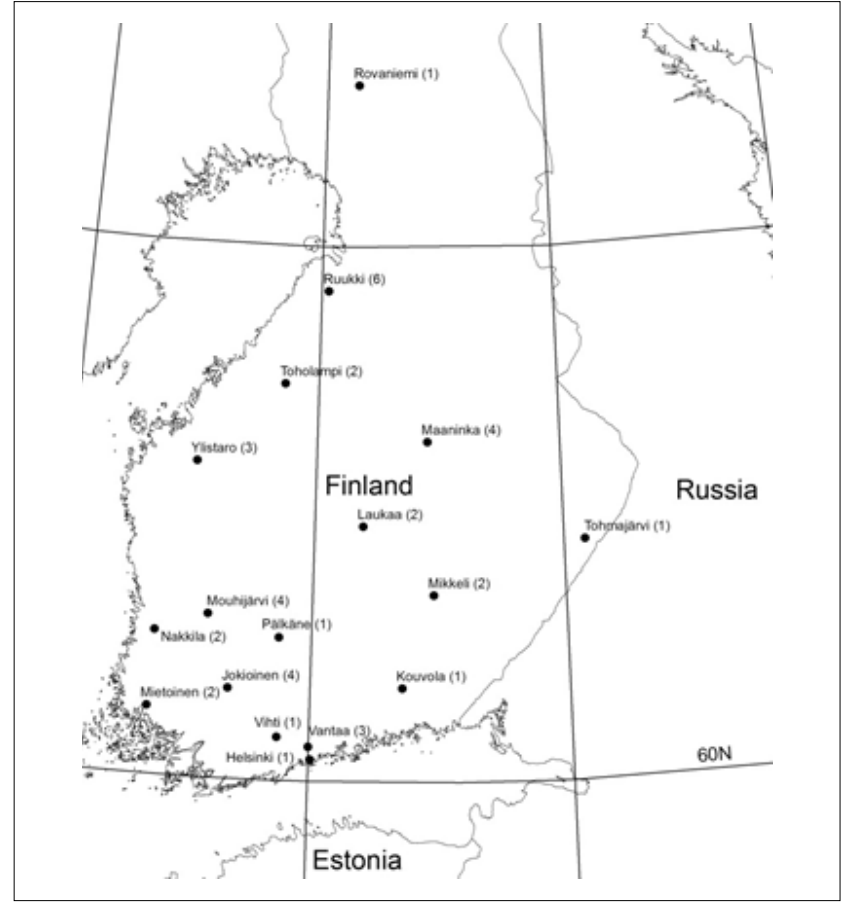

Fig. 1. Location of 40 Finnish $N$ fertilization experiments on grass leys (number of experiments in parenthesis)

where $N$ input was $\mathrm{N}$ applied as inorganic fertilizers;

Noutput was the $\mathrm{N}$ content in the harvested yield.

We calculated $\mathrm{N}$ output as follows:

$N$ output $\left(\mathrm{kg} \mathrm{ha}^{-1}\right)=\operatorname{Protein}(\%) / \mathrm{a} \times$

$\times D M$ Yield $(\mathrm{kg}$ ha-1)/100 (\%),

where $a$ is a coefficient equal to 6.25 .

From the output we excluded any $\mathrm{N}$ lost to the environment through the volatilization of ammonia or denitrification, or leaching, as well as from $\mathrm{N}$ input asymbiotic $\mathrm{N}$ fixation and atmospheric deposition, the latter in Finland amounting to $4-6 \mathrm{~kg} \mathrm{ha}^{-1}[9]$. A negative $\mathrm{N}$ balance thus roughly indicates depletion of the soil $\mathrm{N}$ stocks, whereas a positive balance correlates to accumulation that can increase the risk of losses to the environment.

\section{Effect size calculation}

Meta-analysis and the Meta Win 2.0 statistical program served to analyze the effects of $\mathrm{N}$ fertilization on grass yield and $\mathrm{N}$ balance [10]. For yield data, we used the response ratio (the ratio of mean outcome in the experimental group to that in the control group) as an index of the effect size [11]. We calculated a separate estimate of the natural logarithm of the response ratio for each site, $\mathrm{N}$ rates and randomly selected grass species as:

$$
\ln r=\ln \left(\bar{X}_{\mathrm{PKN}} / X_{\mathrm{PK}}\right) \text {, }
$$

where $\bar{X}_{\mathrm{PKN}}$ and $\bar{X}_{\mathrm{PK}}$ represent yield means for PKN and PK (i.e., the control) treatments, respectively, averaged over the duration of an experiment. $S_{\mathrm{PKN}}$ and $S_{\mathrm{PK}}$ are the corresponding standard deviations, and $n_{\mathrm{PKN}}$ and $n_{\mathrm{PK}}$ are the sample sizes equal to the duration of an experiment in years. To measure the effect of explanatory variables on yield response and to exclude the effect of increasing $\mathrm{N}$ rates, we selected one $\mathrm{N}$ rate, between 117 and $208 \mathrm{~kg} \mathrm{~N} \mathrm{ha}^{-1}$ with a mean of $158 \mathrm{~kg} \mathrm{~N} \mathrm{ha}^{-1}$, per study to ensure statistical independence of $\ln r$.

We then back-transformed log response ratios and reported them in the text as percentage changes from the control:

$$
\text { Yieldresponse }(\%)=[\exp (\operatorname{lnr})-1] \times 100 \text {. }
$$

We considered responses due to $\mathrm{N}$ fertilizer to be significantly different from the control if their $95 \%$ CIs did not overlap with zero.

\section{Yield response models}

Data for yield response models of mineral soils were available from 23 early and 9 recent experiments, from which we randomly selected one grass species or grass mixture and one $\mathrm{N}$ rate per study to ensure statistical independence of $\ln r$. However, due to the small number of studies on organic soils (five early and three recent studies), we selected one grass species or grass mixture and two to three $\mathrm{N}$ rates per study, resulting in 20 observations.

We tested possible sources of variation prior to building a model. To develop a model, we pooled experiments in which variances in the yield response showed no significant difference from those predicted by sampling error alone. We used a two-dimensional Gaussian function to describe the relationship between rising $\mathrm{N}$ rates, $N_{0}$ yield and yield response:

$$
\ln r=a e^{-0.5}\left\{\left[\left(N_{0} \text { yield }-x_{0}\right) / b\right]^{2}+\left[\left(N-y_{0}\right) / c\right]^{2}\right\},
$$

where $\ln r$ is the yield response;

$N_{0}$ yield is the control yield without added $\mathrm{N}$;

$N$ is $\mathrm{N}$ rates;

$b$ and $c$ are standard deviations of $x$ and $y$, respectively;

$x_{0}$ and $y_{0}$ is the center of the model;

$a$ is amplitude.

We ran the models using the SigmaPlot 12.0 program (SYSTAT Software, San Jose, CA, USA) with weights defined by the reciprocal of the sample variance. The Shapiro-Wilk test served to determine whether the weighted residuals (observed yield increase - estimated yield increase) of the model were normally distributed (SYSTAT Software).

Calculation of economically optimal $N$ rates $\left(N_{\text {opt }}\right)$

The following calculation served to derive the grower's profit from the application of $\mathrm{N}$ [12]:

Profit $\left(€ \mathrm{ha}^{-1}\right)=$

$=\left[\right.$ Yield increase due to $\mathrm{N}$ fertilization $\left(\mathrm{kg} \mathrm{ha}^{-1}\right) \times$ $\times$ DM yield value $\left(€ \mathrm{~kg}^{-1}\right)$ ] - A Applied $\mathrm{N}\left(\mathrm{kg} \mathrm{ha}^{-1}\right) \times$

$\times \mathrm{N}$ fertilizer price $\left.\left(€ \mathrm{~kg}^{-1}\right)\right]$. 
We considered the profit from the application of $\mathrm{N}$ optimized when the difference between the extra income due to the yield increase and the cost of the $\mathrm{N}$ fertilizer was at its peak value. The average value of the yield increase term originated from the two-dimensional Gaussian function (Eq. 5). In calculating examples of $N_{\text {opt }}$, we set the average $N_{0} y i e l d s$ to 3900 and $4500 \mathrm{~kg}$ $\mathrm{ha}^{-1}$ for mineral and organic soils, respectively, and the high $N_{0}$ yields to 6000 and $8000 \mathrm{~kg} \mathrm{ha}^{-1}$, respectively. We calculated examples of $N_{\text {opt }}$ for the prices of $\mathrm{N}$ fertilizer $\left(1 € \mathrm{~kg}^{-1}\right)$ and the DM yield values of grass leys $\left(0.1 € \mathrm{~kg}^{-1}\right)$, thus yielding a fertilizer $\mathrm{N}$-to-yield price ratio of ten.

Linear regression analysis

We used a simple linear regression to examine the relationship between $\mathrm{N}$ rates and $\mathrm{N}$ balances:

$$
N_{\text {bal }}=y_{0}+a N \text {, }
$$

where $N_{\text {bal }}$ is the $\mathrm{N}$ balance $\left(\mathrm{kg} \mathrm{ha}^{-1} \mathrm{y}^{-1}\right)$;

$N$ is the $\mathrm{N}$ fertilizer rate $\left(\mathrm{kg} \mathrm{ha}^{-1}\right)$;

$y_{0}$ is the intercept parameter;

$a$ is the slope parameter.

We derived data from 21 early and 7 recent studies on mineral soils and 4 early and 3 recent studies on organic soils. To avoid bias, we randomly selected one grass species and one $\mathrm{N}$ rate per study for the linear regressions, and the average annual $\mathrm{N}$ balance for the duration of an experiment served as a dependent variable. We also tested the data for normal distribution and equal variance.

\section{COUP model}

Precipitation is one of the main drivers of $\mathrm{N}$ leaching. However, field experiments typically represent a limited combination of weather conditions, soils and cultivation practices; therefore, we used climatic data from several years as the driving force to simulate a larger set of $\mathrm{N}$ leaching values. The mathematical model COUP is a dynamic, process-based model for calculating water and heat flux as well as combined carbon $(\mathrm{C})$ and $\mathrm{N}$ cycles in soil profiles [13]. In the present study, we applied the model by using data on the measured physical and chemical soil properties of two practical grass fields (fields 7 and 8) under cattle husbandry [14]. In total, we simulated 96 combinations of weather conditions and cultivation practices. Instead of a hydrological or agricultural year (from autumn to autumn), we used a calendar year to allow sufficient time for $\mathrm{N}$ leaching. The physical and chemical conditions on the field were always the same in the beginning of the simulation, and differences in simulated $\mathrm{N}$ leaching resulted from different rainfalls and temperatures throughout the year.

Due to a lack of runoff water collectors in the practical grass fields, we calibrated the model against measurements of soil mineral $\mathrm{N}$ concentrations in spring and autumn, as well as crop $\mathrm{N}$ uptake. Rankinen et al. [14] previously described the original calibration.

The modeled cases included first-year grass, one year from the middle of the rotation, and the ploughing year (after three years' of grass rotation). We then modeled $\mathrm{N}$ leaching and $\mathrm{N}$ balances to obtain the theoretical upper and lower limits for their relationship by changing the fertilization amounts in steps of $20 \mathrm{~kg}$ $\mathrm{N} \mathrm{ha}{ }^{-1}$. The simulations covered the range of the $\mathrm{N}$ balance from -100 to $150 \mathrm{~kg} \mathrm{ha}^{-1}$. We simulated a set of individual cases by using one-year datasets for the entire five-year period. We therefore did not include simulated $\mathrm{N}$ accumulation in the soil, but started all annual simulations from the observed physical and chemical properties of the soil.

\section{Results AND discussion}

\section{Yield response models}

We developed the models separately for mineral and organic soils, and since $N_{0}$ yield substantially affected the yield responses, we included it as an independent variable along with $\mathrm{N}$ rates (Table 1 ). The coefficients of determination $\left(R^{2}\right)$ indicated that the $\mathrm{N}$ rate and $N_{0}$ yields together accounted for $80-95 \%$ of the variation in the yield response of grass leys.

\begin{tabular}{|c|c|c|c|c|c|c|c|c|}
\hline \multicolumn{9}{|c|}{$\begin{array}{lll}\text { Table } 1 \\
\end{array}$} \\
\hline $\begin{array}{l}\text { PARAMETE } \\
\text { RELATIONS } \\
\text { N RATE ( }\end{array}$ & $\begin{array}{l}\text { S AND } \\
\text { HIP BE } \\
\text { N, KG }\end{array}$ & $\begin{array}{l}\text { FITTINGS } \\
\text { WEEN YI } \\
\text { IA } A^{-1} \text { ) AND }\end{array}$ & $\begin{array}{l}\text { OF THE } \\
\text { ELD WII } \\
\text { O YIELD } \\
\text { ORGAI }\end{array}$ & $\begin{array}{l}\text { WEIGI } \\
\text { HOUT } \\
\text { RESPO } \\
\text { IC SOI }\end{array}$ & $\begin{array}{l}\text { FED M } \\
\text { DDED } \\
\text { SE (LI }\end{array}$ & $\begin{array}{l}\text { ELS } \\
\left(N_{0}\right. \\
\text { ) } 01\end{array}$ & $\begin{array}{l}\text { SCRIB } \\
\text { LD, KG } \\
\text { INERA }\end{array}$ & $\begin{array}{l}\text { IG THE } \\
\left.\text { (A } A^{-1}\right), \\
\text { AND }\end{array}$ \\
\hline \multirow{2}{*}{$\begin{array}{l}\text { Soil } \\
\text { type }\end{array}$} & \multicolumn{8}{|c|}{$\ln r=a e^{-0.5}\left\{\left[\left(N_{0} \text { yield }-x_{0}\right) / b\right]^{2}+\left[\left(N-y_{0}\right) / c\right]^{2}\right\}$} \\
\hline & $a$ & $x_{0}$ & $\boldsymbol{b}$ & $y_{0}$ & $c$ & $R^{2}$ & $\underset{\text { test }}{F}$ & $n$ \\
\hline Mineral & 3010 & -62253 & 16429 & 466 & 383 & 0.80 & 28 & 32 \\
\hline Organic & 135 & -35349 & 12067 & 345 & 214 & 0.95 & 87 & 20 \\
\hline \multicolumn{9}{|c|}{$\begin{array}{l}\text { Bold numbers indicate } \mathrm{P}<0.0001 \text {; } \\
n \text { indicates number of experiments for mineral soils and number } \\
\text { of observations for organic soils. For back-transformation of } \ln r \text {, } \\
\text { see Equation } 4 \text {. } \\
\text { The models are valid for } \mathrm{N} \text { rates }>50 \mathrm{~kg} \mathrm{ha}^{-1} \text { (mineral soils) and } \mathrm{N} \\
\text { rates }>75 \mathrm{~kg} \mathrm{ha}^{-1} \text { (organic soils). }\end{array}$} \\
\hline
\end{tabular}

The models estimated that the yield response to $\mathrm{N}$ rates decreased considerably with increasing $N_{0}$ yield (Fig. 2). On mineral soils, for example, the largest yield response over that of the control dropped from $318 \%$ ( $\ln r=1.43)$ to $70 \%(\ln r=0.54)$ while increasing the $N_{0}$ yield from 2000 to $6000 \mathrm{~kg} \mathrm{ha}^{-1}$ (Fig. 2a). Respectively, on organic soils, the largest response dropped from $200 \%(\ln r=1.1)$ to $23 \%(\ln r=0.21)$ while increasing the $N_{0}$ yield from 2000 to $8000 \mathrm{~kg} \mathrm{ha}^{-1}$.

\section{$N$ balance}

We performed the linear regression analysis between rising $\mathrm{N}$ rates and $\mathrm{N}$ balance (Fig. 3, Table 2). The coefficient of determination $\left(R^{2}\right)$ indicated that $86-88 \%$ of the variation in the $\mathrm{N}$ balance stemmed from its relationship with the $\mathrm{N}$ rates. On mineral soils, an increase of $10 \mathrm{~kg} \mathrm{~N} \mathrm{ha}^{-1}$ associated with an average increase of 4.8 (4.1-5.6) $\mathrm{kg} \mathrm{ha}^{-1} \mathrm{yr}^{-1}$ in the $\mathrm{N}$ balance, 
and on organic soils, with an average increase of 6.4 (3.4-9.4) $\mathrm{kg} \mathrm{ha}^{-1} \mathrm{yr}^{-1}$, respectively. According to the regressions, adding no $\mathrm{N}$ fertilizer yielded an $\mathrm{N}$ balance equal on average to -53 ( -71 to -35$) \mathrm{kg} \mathrm{ha}^{-1} \mathrm{yr}^{-1}$ on mineral soils and to -123 (-203 to -42$) \mathrm{kg} \mathrm{ha}^{-1} \mathrm{yr}^{-1}$ on organic soils. We expected a zero $\mathrm{N}$ balance at average $\mathrm{N}$ rates of 110 and $192 \mathrm{~kg} \mathrm{ha}^{-1}$ in mineral and organic soils, respectively.
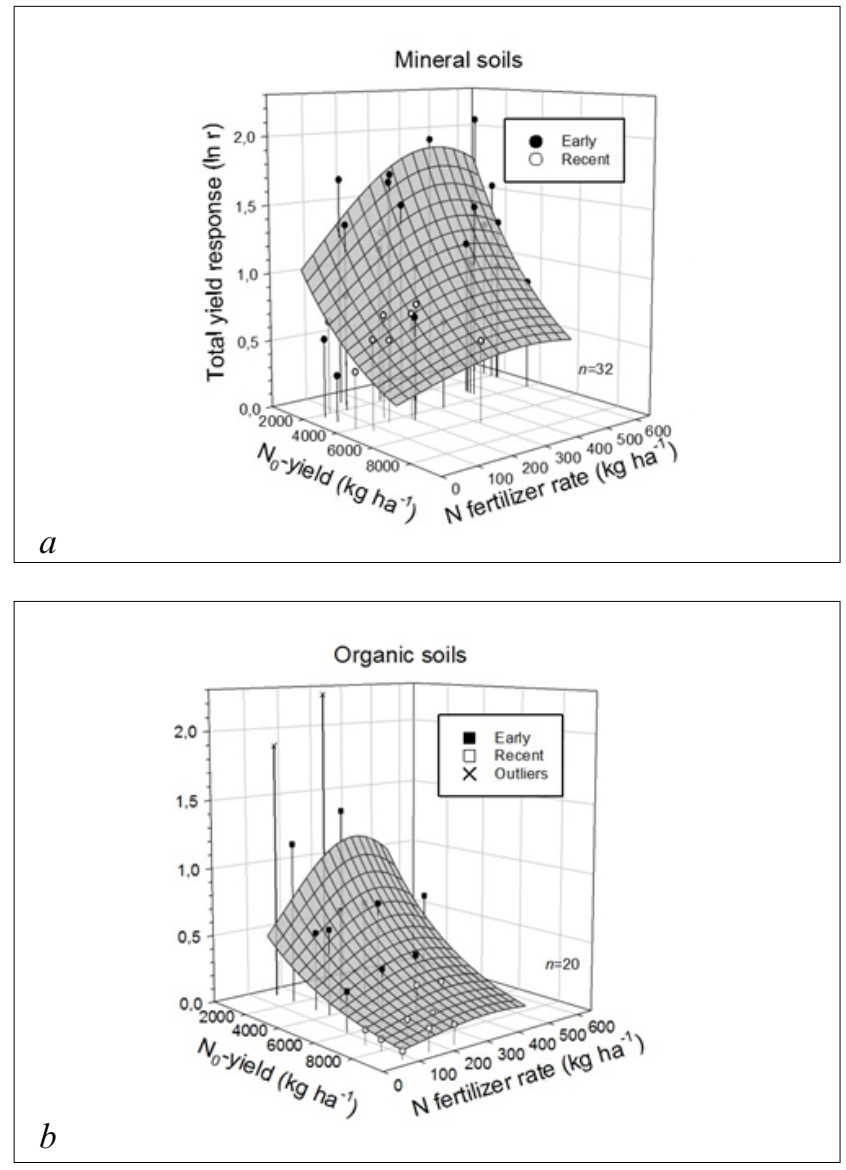

Fig. 2. Total yield response of grass leys $(\ln r)$ in relation to the $N$ fertilizer rate and control yield without added $N$ ( $N_{0}$ yield) on (a) mineral and (b) organic soils in early (1950s-1970s) and recent (1990s-2000s) studies. Each symbol represents the average yield response for the duration of an experiment; $n$ represents the number of experiments in (a) and the number of observations in (b). For back-transformation of $\ln r$, see Equation (4)
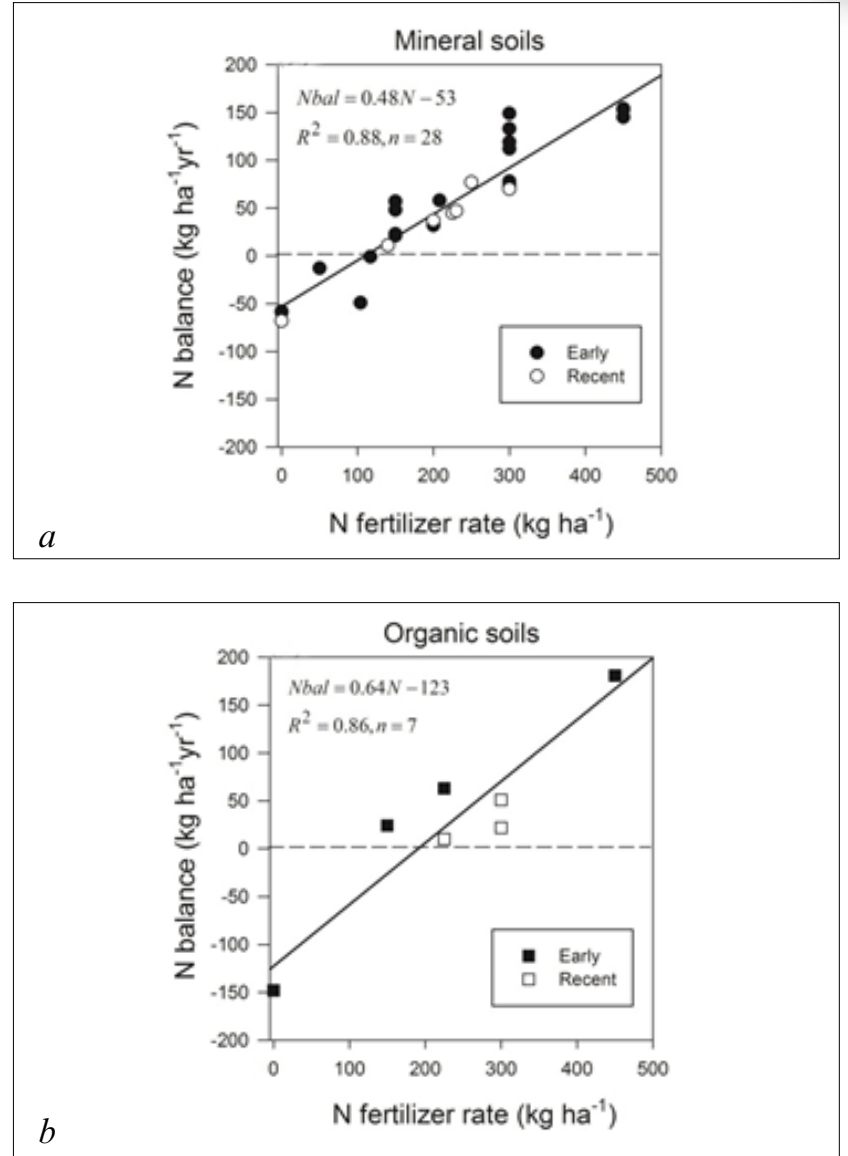

Fig. 3. The relationship between increasing $N$ fertilizer rates and $N$ balances on (a) mineral and (b) organic soils in early (1950s-1970s) and recent (2000s) studies (each symbol represents the average annual $N$ balance for the duration of an experiment; $n$ represents the number of experiments)

\section{Observed and simulated $N$ leaching loss from mineral} soils

The review of published Nordic studies showed that the smallest observed annual $\mathrm{N}$ leaching loss was $1.2 \mathrm{~kg} \mathrm{ha}^{-1}$ from clay soil and the largest value was $13 \mathrm{~kg} \mathrm{ha}^{-1}$ from sand soil (Fig. 4a). Within the range of observations, $\mathrm{N}$ leaching showed no clear relationship with $\mathrm{N}$ balances. For example, a large range of $\mathrm{N}$ balances (e.g., -80 to $105 \mathrm{~kg} \mathrm{ha}^{-1} \mathrm{yr}^{-1}$ ) across several experiments yielded annual $\mathrm{N}$ leaching losses as low

\begin{tabular}{|c|c|c|c|c|c|c|c|c|c|c|}
\hline \multicolumn{11}{|c|}{ 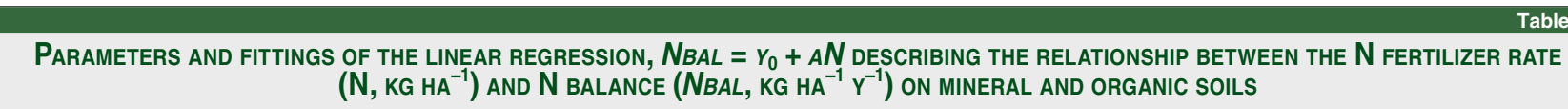 } \\
\hline \multirow{2}{*}{ Soil type } & \multirow{2}{*}{\multicolumn{2}{|c|}{ Coefficients }} & \multirow{2}{*}{$t$} & \multirow{2}{*}{$\boldsymbol{P}$} & \multicolumn{2}{|c|}{ 95\% CIs } & \multirow{2}{*}{$R^{2}$} & \multirow{2}{*}{ F test } & \multirow{2}{*}{$\boldsymbol{P}$} & \multirow{2}{*}{$n$} \\
\hline & & & & & Low & Up & & & & \\
\hline \multirow{2}{*}{ Mineral } & $y_{0}$ & -53 & -6.1 & $* * * *$ & -71 & -35 & \multirow{2}{*}{0.88} & \multirow{2}{*}{194} & \multirow{2}{*}{$* * * *$} & \multirow{2}{*}{28} \\
\hline & $\mathrm{a}$ & 0.48 & 13.9 & $* * * *$ & 0.41 & 0.56 & & & & \\
\hline \multirow{2}{*}{ Organic } & $y_{0}$ & -123 & -3.9 & $*$ & -203 & -42 & \multirow{2}{*}{0.86} & \multirow{2}{*}{31} & \multirow{2}{*}{$* *$} & \multirow{2}{*}{7} \\
\hline & $\mathrm{a}$ & 0.64 & 5.5 & $* *$ & 0.34 & 0.94 & & & & \\
\hline
\end{tabular}



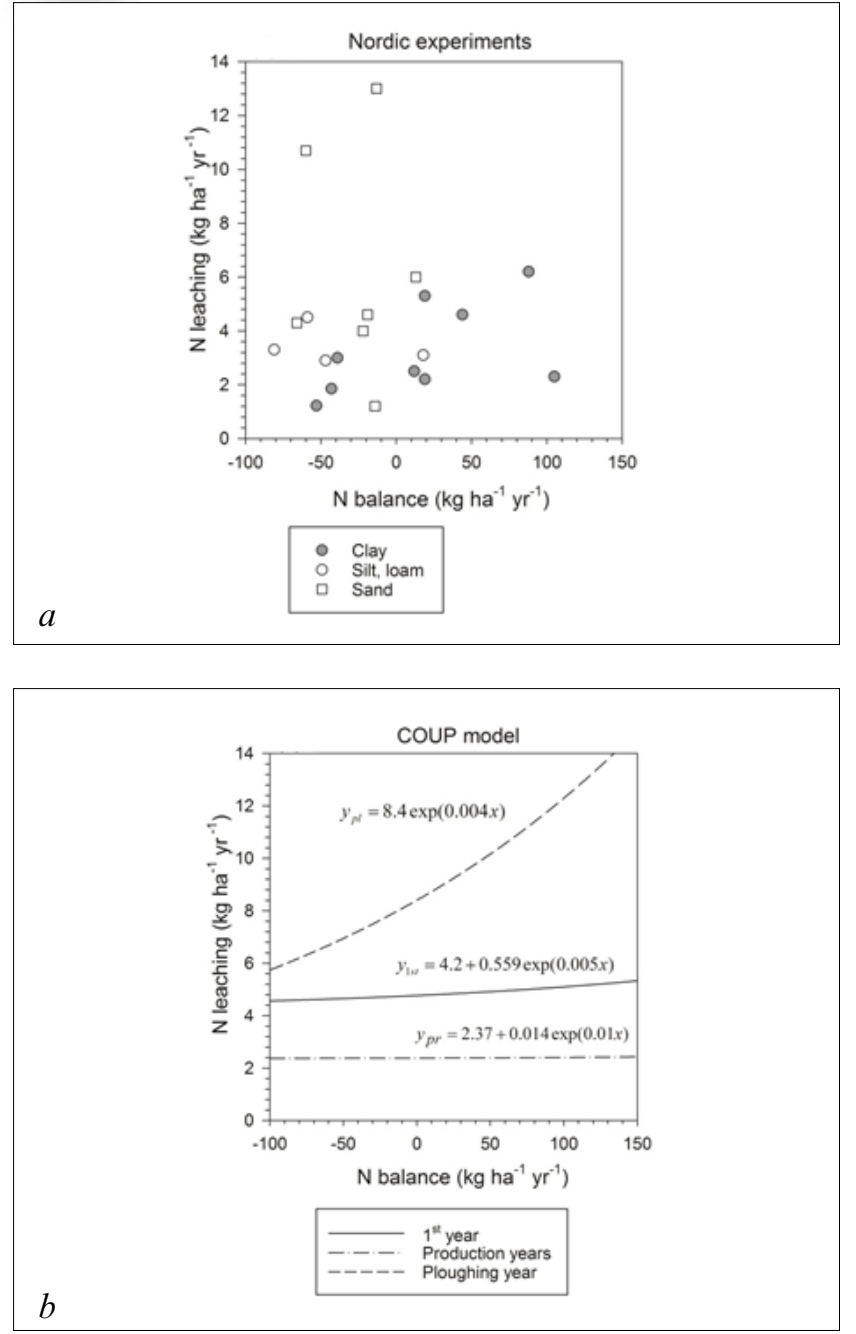

Fig. 4. Leaching losses:

$a$-values of $N$ leaching losses and $N$ balances measured after the application of mineral $N$ fertilizer to perennial grass leys in Nordic experiments; $b$-simulated $N$ leaching losses on mineral soils in relation to $N$ balances for different years of grass production (The observed values in (a) were averaged over the duration of an experiment) as $2-4 \mathrm{~kg} \mathrm{ha}^{-1}$ (Fig. 4a). On the other hand, with a narrow range for the $\mathrm{N}$ balance (e.g., $10-20 \mathrm{~kg} \mathrm{ha}^{-1} \mathrm{yr}^{-1}$ ), $\mathrm{N}$ leaching losses varied from 2.2 to $6.0 \mathrm{~kg} \mathrm{ha}^{-1} \mathrm{yr}^{-1}$.

Simulated $\mathrm{N}$ leaching loss for the first year of grass production increased slowly, by $0.6 \mathrm{~kg} \mathrm{ha}^{-1} \mathrm{yr}^{-1}$, with an $\mathrm{N}$ balance rising from -100 to $100 \mathrm{~kg} \mathrm{ha}^{-1} \mathrm{yr}^{-1}$ (Fig. 4 b). During production years, the $\mathrm{N}$ leaching loss was low $\left(2.4 \mathrm{~kg} \mathrm{ha}^{-1} \mathrm{yr}^{-1}\right)$ for the range of $\mathrm{N}$ balances. In contrast, for the last year of grass production involving autumn ploughing and bare soil over the following winter, simulated $\mathrm{N}$ leaching increased from 5.6 to 12.5 $\mathrm{kg} \mathrm{ha}^{-1} \mathrm{yr}^{-1}$ when $\mathrm{N}$ balances rose from -100 to $100 \mathrm{~kg} \mathrm{ha}^{-1} \mathrm{yr}^{-1}$. An N input of $110 \mathrm{~kg} \mathrm{ha}^{-1}$ would then yield a zero $\mathrm{N}$ balance and an $\mathrm{N}$ leaching loss of $8.4 \mathrm{~kg} \mathrm{ha}^{-1} \mathrm{yr}^{-1}$. In the driest year, however, when the simulated runoff from fields was about $210 \mathrm{~mm}$, simulated $\mathrm{N}$ leaching during the ploughing year was low (about $2.7 \mathrm{~kg} \mathrm{ha}^{-1} \mathrm{yr}^{-1}$ ) regardless of rising $\mathrm{N}$ balances.

Regarding organic soils under grass leys, we were unable to simulate $\mathrm{N}$ leaching losses after the application of mineral $\mathrm{N}$ fertilizer or to survey articles published in Nordic countries due to lack of data and experiments.

Estimates of Nopt, respective $N$ balance and $N$ leaching loss

We estimated $N_{\text {opt }}$ separately for average and high $N_{0}$ yields and compared them to the Finnish AgriEnvironmental Programme's maximum permissible $\mathrm{N}$ rates $\left(N_{\max }\right)$ [15]. For both mineral and organic soils, Nopt clearly depends on $N_{0}$ yields: to maximize profit, a field with high $N_{0}$ yields requires only $20-40 \%$ of the $\mathrm{N}$ fertilizer needed for a field with average $N_{0}$ yields, resulting in negative $\mathrm{N}$ balances (Table 3).

For the average $N_{0}$ yields in mineral soils, estimates demonstrated that at a fertilizer $\mathrm{N}$-to-yield price ratio of ten, $\mathrm{N}_{\text {opt }}$ is equivalent to the permitted $\mathrm{N}_{\max }\left(230 \mathrm{~kg} \mathrm{ha}^{-1}\right)$ for soils rich in SOM, yielding an N balance of $57 \mathrm{~kg} \mathrm{ha}^{-1} \mathrm{yr}^{-1}$ and a simulated $\mathrm{N}$ leaching loss of 2.4-10.6 $\mathrm{kg} \mathrm{ha}^{-1} \mathrm{yr}^{-1}$. In contrast, the application of permitted $N_{\max }$ to fields

\begin{tabular}{|c|c|c|c|c|c|c|}
\hline \multirow{3}{*}{ Estimates } & \multicolumn{3}{|c|}{ Mineral soils } & \multicolumn{3}{|c|}{ Organic soils } \\
\hline & \multicolumn{2}{|c|}{$N_{\text {opt }} *$} & \multirow{2}{*}{$\frac{N_{\max } * *}{230}$} & \multicolumn{2}{|c|}{$N_{\text {opt }}$} & \multirow{2}{*}{$\begin{array}{c}N_{\max } \\
190\end{array}$} \\
\hline & 230 & 50 & & 190 & 75 & \\
\hline$N_{0}$ yield $\left(\mathrm{kg} \mathrm{ha}^{-1}\right)$ & $\begin{array}{c}3900 \\
\text { (average) }\end{array}$ & $\begin{array}{c}6000 \\
\text { (high) }\end{array}$ & $\begin{array}{c}6000 \\
\text { (high) }\end{array}$ & $\begin{array}{c}4500 \\
\text { (average) }\end{array}$ & $\begin{array}{c}8000 \\
\text { (high) }\end{array}$ & $\begin{array}{c}8000 \\
\text { (high) }\end{array}$ \\
\hline Yield increase due to $\mathrm{N}\left(\mathrm{kg} \mathrm{ha}^{-1}\right)$ & 4400 & 2100 & 3400 & 2500 & 800 & 1400 \\
\hline Profit from $\mathrm{N}$ fertilizer $\left(€ \mathrm{ha}^{-1}\right)^{* * *}$ & 206 & 159 & 106 & 62 & 6 & -48 \\
\hline $\mathrm{N}$ balance $\left(\mathrm{kg} \mathrm{ha}^{-1} \mathrm{yr}^{-1}\right)$ & 57 & -29 & 57 & -1 & -75 & -1 \\
\hline Simulated $\mathrm{N}$ leaching losses $\left(\mathrm{kg} \mathrm{ha}^{-1} \mathrm{yr}^{-1}\right) * * * *$ & $2.4-10.6$ & $2.4-7.5$ & $2.4-10.6$ & \multicolumn{3}{|c|}{ Not simulated } \\
\hline
\end{tabular}


with the high $N_{0}$ yields would be uneconomically high and could be therefore reduced to $50 \mathrm{~kg} \mathrm{ha}^{-1}$. However, despite the considerably lower $\mathrm{N}$ rate and $\mathrm{N}$ balance attained, and even negative values for the latter, the simulated annual $\mathrm{N}$ leaching loss would decrease by only $3.1 \mathrm{~kg} \mathrm{ha}^{-1}$.

Similarly, in organic soils with average $N_{0}$ yields, $N_{\text {opt }}$ is equivalent to $N_{\max }$ (i.e., $190 \mathrm{~kg} \mathrm{ha}^{-1}$ ), resulting in an $\mathrm{N}$ balance of about zero. Again, in fields with high $N_{0}$ yields, $\mathrm{N}$ rates could be reduced up to $75 \mathrm{~kg} \mathrm{ha}^{-1}$, since the application of $N_{\max }$ to such fields would pose a financial burden on growers. This practice would reduce the $\mathrm{N}$ balance to $-75 \mathrm{~kg} \mathrm{ha}^{-1} \mathrm{yr}^{-1}$. For organic soils, we were unable to assess the associated environmental impact.

\section{Yield response}

From the growers' point of view, fertilizer applications should be based on relevant yield response models and be economically justified. However, year-to-year, sitespecific and climatic variability leads to numerous response curves as well as uncertainty in estimating $N_{\text {opt }}$. To overcome these challenges, we applied metaanalysis in the present study to test the sources of variation and to improve the robustness and reliability of the yield response curves. They were fitted to average grass yield increases over the duration of an experiment and to a large number of experiments on different soils located at 17 sites with growth periods ranging from 130 to 175 days. In our previous meta-analysis of cereals, the $N_{0}$ yield was a major factor governing the magnitude of the yield response to $\mathrm{N}$ fertilization [2]. In this study we included the $N_{0}$ yields as a continuous variable that enabled improvement of the models' reliability $\left(R^{2}=0.80-0.95\right)$.

Although SOM is broadly recognized as an important parameter affecting soil quality and crop yield, large dataset analyses of cereals have shown either its weak correlation with $N_{0}$ yield [2] or no statistically significant correlations at all [16]. The latter result agreed with that of the present study on grass leys. We suggest that the variations in $N_{0}$ yield observed in the present study were determined largely by unaccounted factors such as e.g., soil structure. Soil structure can influence crop yields by affecting root growth and distribution, soil aeration, water availability, as well as soil microbial activity and nutrient cycling.

In light of the present results, current fertilizer recommendations, which are based on the grower's yield expectation (i.e., the higher the expected yield, the higher the $\mathrm{N}$ fertilization), do not lead to optimal $\mathrm{N}$ management. Indeed, the $N_{\text {max }}$ permitted by FAEP on a field without consideration of its $N_{0}$ yield and responsiveness may be unnecessarily high and lead to excessive $\mathrm{N}$ inputs and thus to economic losses for a grower. According to the models, on low responsive fields the application of permitted $N_{\max }$ would lead to a yield increase of $1000 \mathrm{~kg} \mathrm{ha}^{-1}$ less than on highly responsive fields, regardless of the soil type. Thus, the yield response models developed in the present study can contribute to the construction of a dynamic tool for growers to more effectively adjust $\mathrm{N}$ applications in order to maximize economic profitability. However, such a tool would require growers to estimate the magnitude of $N_{0}$ yields from his fields by, for example, leaving some representative areas unfertilized for a few years.

\section{$N$ balance and $N$ leaching loss}

This study showed that $\mathrm{N}$ rates explained a large part of the variation (86-88\%) in $\mathrm{N}$ balances for grass leys, which agrees with the results of our previous study on cereals [2], and the effect of $\mathrm{N}$ fertilization on $\mathrm{N}$ balance was consistent across the studies. The results also indicate that for grass production on mineral soils, as with wheat production, an increase of $10 \mathrm{~kg} \mathrm{ha}^{-1}$ in fertilization associated with about $5 \mathrm{~kg} \mathrm{ha}^{-1}$ increase in the $\mathrm{N}$ balances [2].

On organic soils, the application of $N_{\max }$ permitted by the FAEP (i.e., $190 \mathrm{~kg} \mathrm{ha}^{-1}$ ), the $\mathrm{N}$ balance would be approximately zero. On mineral soils, the larger $N_{\max }\left(230 \mathrm{~kg} \mathrm{~N} \mathrm{ha}^{-1}\right)$ would result in an $\mathrm{N}$ balance of $57 \mathrm{~kg} \mathrm{ha}^{-1} \mathrm{yr}^{-1}$, slightly exceeding the average national $\mathrm{N}$ balance of $50 \mathrm{~kg} \mathrm{ha}^{-1} \mathrm{yr}^{-1}$ [9]. In particular, growers could reduce $\mathrm{N}$ inputs on mineral soils with high $N_{0}$ yields considerably, down to $50 \mathrm{~kg} \mathrm{ha}^{-1}$, and the $\mathrm{N}$ balance down to $-29 \mathrm{~kg} \mathrm{ha}^{-1} \mathrm{yr}^{-1}$ with no economic loss. Similarly, the respective cases for spring wheat production have the potential to reduce $\mathrm{N}$ inputs from 120 to $45 \mathrm{~kg} \mathrm{ha}^{-1}$ and the $\mathrm{N}$ balance from 33 to $5 \mathrm{~kg} \mathrm{ha}^{-1} \mathrm{yr}^{-1}$ with no economic loss [2].

The values predicted by the COUP model for $\mathrm{N}$ leaching losses after the application of mineral $\mathrm{N}$ fertilizer to perennial grass leys were in accordance with the low values measured, which ranged from 1.2 to $10-15 \mathrm{~kg} \mathrm{ha}^{-1} \mathrm{yr}^{-1}$ in Finland [5] and in the NordicBaltic countries [17, 18]. Numerous studies demonstrated that $\mathrm{N}$ leaching losses from perennial grassland are inherently smaller than those from arable land, since $\mathrm{N}$ uptake covers a longer period and the soil normally remains untilled for at least three years, thereby reducing $\mathrm{N}$ leaching [19-21].

Even with wide variation across management regimes and years, a recent Danish study of grasslands under different grazing, cutting and manure treatments found that $\mathrm{N}$ surpluses related only weakly to $\mathrm{N}$ leaching and accounted for only 5\% of the variation, thus revealing the huge capacity of soils to accumulate large $\mathrm{N}$ inputs [3]. The model in the present study predicted a weak relationship between $\mathrm{N}$ leaching losses and $\mathrm{N}$ balances on mineral soils, but only for inorganic $\mathrm{N}$ input. Even in a ploughing year, when $\mathrm{N}$ leaching losses were expected to rise due to mineralization and the accumulation of inorganic $\mathrm{N}$ in the soil [22], simulated 
$\mathrm{N}$ losses rose by only $6.9 \mathrm{~kg} \mathrm{ha}^{-1} \mathrm{yr}^{-1}$, when $\mathrm{N}$ balances rose considerably by $200 \mathrm{~kg} \mathrm{ha}^{-1} \mathrm{yr}^{-1}$.

Assessments have shown that, along with the low $\mathrm{N}$ leaching loss, also the volatilization of ammonia and nitrous oxide from grass leys on mineral soils with the recommended rates of mineral $\mathrm{N}$ fertilizers have been low, about 1 and $1.5-4 \mathrm{~kg} \mathrm{ha}^{-1} \mathrm{yr}^{-1}$, respectively $[9,23]$. This indicates that an $\mathrm{N}$ balance of $57 \mathrm{~kg} \mathrm{ha}^{-1} \mathrm{yr}^{-1}$ contributes to a residual soil $\mathrm{N}$ pool that amounts to about $40-50 \mathrm{~kg} \mathrm{ha}^{-1} \mathrm{yr}^{-1}$. In grasslands, the largest pool of $\mathrm{N}$ is $\mathrm{SOM}$, and since the net $\mathrm{N}$ mineralization rate is generally low, the residence time of $\mathrm{N}$ in SOM in most undisturbed grasslands would be decades or even centuries [24].

However, the ploughing of grass leys receiving mineral fertilizer with the subsequent cultivation of spring cereals may either return $\mathrm{N}$ leaching losses to the pre-ley levels [25] or slightly raise it by $3 \mathrm{~kg} \mathrm{ha}^{-1} \mathrm{yr}^{-1}$ during the two to three years after ploughing [26]. In the cereal phase of grass-arable rotation, the undersowing of non-legume catch crops, such as ryegrass, is considered an effective strategy for avoiding $\mathrm{N}$ losses [27]. A recent meta-analysis confirmed that using catch crops in spring cereal production reduced $\mathrm{N}$ leaching losses by $50 \%$ across the range of soils and weather conditions in the Nordic countries [28].

Along with commercial fertilizers, the use of animal manure on grasslands is commonplace. On a catchment scale, $\mathrm{N}$ balances in areas that received manure applications are often higher than those that received only mineral fertilizer [1]. In addition to the quantity of $\mathrm{N}$ applied, $\mathrm{N}$ losses from manure depend on several other factors, such as the timing and method of application, particularly in relation to subsequent rainfall [20]. In contrast to inorganic $\mathrm{N}$ input, the application of slurry can lead to higher $\mathrm{N}$ leaching losses of up to $60-190 \mathrm{~kg} \mathrm{ha}^{-1}[3$, 5]. In grazed pasture, the potential for $\mathrm{N}$ leaching increases more than five-fold that of mowed pastures [29], since a large proportion (between 60-90\%) of the $\mathrm{N}$ ingested returns to the soil pasture system as urine and manure.

Conclusions. In grass ley production, $\mathrm{N}$ fertilizer management should aim for $N_{\text {opt }}$ as determined by $N_{0}$ yields. Otherwise, $\mathrm{N}$ input may be unnecessarily high, leading to economic losses for growers. We propose that unaccounted factors, such as soil structure, largely caused the variations in $N_{0} y i e l d$ observed in the field experiments summarized in the present study. Growers are therefore encouraged to estimate the magnitude of $N_{0}$ yields directly from their fields by, for example, leaving some representative areas unfertilized for a few years. On mineral soils, however, concerns about the risk of $\mathrm{N}$ leaching losses when using only inorganic $\mathrm{N}$ fertilization seems less crucial due to its low level and weak association with $\mathrm{N}$ balances. Further research is needed to explore the relationship between $\mathrm{N}$ balances and $\mathrm{N}$ leaching on organic soils.

\section{REFERENCE}

1. Bechmann M., Blicher-Mathiesen G., Kyllmar K., Iital A., Lagzdins A., Salo T. Nitrogen application, balances and their effect on water quality in small catchments in the NordicBaltic countries. Agric. Ecosyst. Environ. 2014. 198. 104-113 (In English).

2. Valkama E., Salo T., Esala M., Turtola E., Nitrogen balances and yields of spring cereals as affected by nitrogen fertilization in northern conditions: a meta-analysis. Agric. Ecosyst. Environ. 2013. 164. 1-13 (In English).

3. Eriksen J., Askegaard M., Rasmussen J., Søegaard, K. 2015. Nitrate leaching and residual effect in dairy crop rotations with grass-clover leys as influenced by sward age, grazing, cutting and fertilizer regimes. Agric. Ecosys. Environ. 2015. 212. 75-84 (In English).

4. Hansen E.M., Munkholm L.J., Olesen J.E., Melander B. Nitrate leaching, yields and carbon sequestration after noninversion tillage, catch crops, and straw retention. $J$. Environ. Qual. 2015. 44. 868-881 (In English).

5. Salo T., Turtola E. Nitrogen balance as an indicator of nitrogen leaching in Finland. Agric. Ecosyst. Environ. 2006. 113. 98-107 (In English).

6. Wachendorf M., Büchter M., Trott H., Taube F. Performance and environmental effects of forage production on sandy soils. II. Impact of defoliation system and nitrogen input on nitrate leaching losses. Grass Forage Sci. 2004. 59. 56-68 (In English).

7. European Environment Agency. Nitrogen balance per hectare of agricultural land. 2015. http://www.eea.europa. eu/data-and-maps/figures/nitrogen-balance-per-hectare-ofagricultural-land\#tab-european-data. Web address verified 05.04.2019 (In English).

8. OECD. Environmental Indicators for Agriculture, Methods and Results. Organization for economic co-operation and development. Paris. France. 2001 (In English).

9. Salo T., Lemola R., Esala M. National and regional net nitrogen balances in Finland in 1990-2005. Agric. Food Sci. 2007. 16. 366-375 (In English).

10. Rosenberg M.S., Adams D.C., Gurevitch J. Metawin: Statistical Software for Meta-analysis, Version 2.1. Sinauer Associates, Inc, Sunderland. 2000. MA, USA (In English).

11. Hedges L.V., Gurevitch J., Curtis P.S. The meta-analysis of response ratios in experimental ecology. Ecol. 1999. 80. 1150-1156 (In English).

12. McConnell D.J., Dillon J.L. Optimization of resource use levels: response analysis, in: McConnell, D.J., Dillon J.L. (Eds.). Farm management for Asia: a systems approach. 1997. FAO Farm Systems Management Series N13. Food and Agriculture Organization of the United Nations. Rome. 
Italy. 169-188 (In English).

13. Jansson P.E., Karlberg L. Coupled heat and mass transfer model for soil-plant-atmosphere systems. TRITA-AMI Report 30 87. Division of Land and Water Resources, Department of Civil and Environmental Engineering, Royal Institute of Technology. Stockholm. 2001. 321 (In English).

14. Rankinen K., Salo T., Granlund K., Rita H. Simulated nitrogen leaching, nitrogen mass field balances and their correlation on four farms in south-western Finland during the period 2000-2005. Agric. Food Sci. 2007. 16. 387-406 (In English).

15. Government regulation of environmental compensation. 2015. https://www.finlex.fi/fi/laki/alkup/2015/20150235. Web address verified 08.02.2019 (In Finnish).

16. Oelofse M., Markussen B., Knudsen L., Schelde K., Olesen J.E., Jensen L., Bruun S. Do soil organic carbon levels affect potential yields and nitrogen use efficiency? An analysis of winter wheat and spring barley field trials. Eur. J. Agron. 2015. 66. 62-73 (In English).

17. Korsaeth A., Bakken L.R., Riley H. Nitrogen dynamics of grass as affected by $\mathrm{N}$ input regimes, soil texture and climate: lysimeter measurements and simulations. Nutr. Cycl. Agroecosys. 2003. 66: 181-199 (In English).

18. Sileika A.S., Gaigalis K., Kutra G., Smitiene A. Factors affecting $\mathrm{N}$ and $\mathrm{P}$ losses from small catchments (Lithuania). Environ. Monit. Assess. 2005. 102. 359-374 (In English).

19. Korsaeth A., Eltun R. Nitrogen mass balances in conventional, integrated and ecological cropping systems and the relationship between balance calculations and nitrogen runoff in an 8-year field experiment in Norway. Agric. Ecosyst. Environ. 2000. 79. 199-214 (In English).

20. Addiscott T. M. Losses of Nitrogen from grassland, in: Addiscott T. M.(Ed.), Nitrate, Agriculture and the Environment. UK, Wallingford: CABI Publishing. 2005. 93-109 (In English).

Конфликт интересов. Авторы заявляют об отсутствии конфликта интересов.
21. Aronsson H., Liu J., Ekre E., Torstensson G., Salomon E. Effects of pig and dairy slurry application on $\mathrm{N}$ and $\mathrm{P}$ leaching from crop rotations with spring cereals and forage leys. Nutr. Cycl. Agroecosyst. 2014. 98. 281-293 (In English). 22. Wallgren B., Lindén B. Effect of catch crops and ploughing times on soil mineral nitrogen. Swedish J. Agric. Res. 1994. 24. 67-75 (In English).

23. Virkajärvi P., Maljanen M., Saarijärvi K., Haapala J., Martikainen P.J. N2O emissions from boreal grass and grassclover pasture soils. Agric. Ecosyst. Environ. 2010. 137. 5967 (In English).

24. Wedin D.A., Russelle M.P. Nutrient cycling in forage production systems, in: Moore K.J., Barnes R.F., Nelson C.J., Collins M. (Eds.), Forages: The Science of Grassland Agriculture, vol. II. Blackwell Publ. Ames, IA, USA. 2007. 37-148 (In English).

25. Christensen B.T., Rasmussen J., Eriksen J., Hansen E.M. Soil carbon storage and yields of spring barley following grass leys of different age. Eur. J. Agron. 2009. 31. 29-35 (In English).

26. Turtola E., Jaakkola A. Viljelykasvin vaikutus ravinteiden huuhtoutumiseen savimaasta Jokioisten huuhtoutumiskentällä V. 1983-1986. Tiedote 22/87. MTT Agrifood Research Finland, Jokioinen. 1987 (In Finnish).

27. Eriksen J., Askegaard M., Søegaard K. Residual effect and nitrate leaching in grass-arable rotations: effect of grassland proportion, sward type and fertilizer history. Soil Use Manage. 2008. 24. 373-382 (In English).

28. Valkama E., Lemola R., Känkänen H., Turtola E. Metaanalysis of the effects of undersown catch crops on nitrogen leaching loss and grain yields in the Nordic countries. Agric. Ecosyst. Environ. 2015. 203. 93-101 (In English).

29. Ryden J.C., Ball P.R., Garwood E.A. Nitrate leaching from grassland. Nature. 1984. 311. 50-53 (In English).

Conflict of interest. The authors declare no conflict of interest.
Статья поступила в редакцию 28.03.2019 The paper was submitted to the Editorial Office on 28.03.2019
Статья принята к публикации 12.04.2019

The paper was accepted for publication on 12.04.2019 